\title{
Comparative Evaluation of Garlic (Allium sativum L.) Genotypes in Kanthalloor, Idukki, Kerala, India
}

\author{
S.N. Shibana* and Jalaja S. Menon \\ Kerala Agricultural University, India \\ *Corresponding author
}

\begin{abstract}
A B S T R A C T
Keywords

Garlic, Genotypes, Yield, Quality, Kanthalloor

Article Info

Accepted:

07 March 2019

Available Online:

10 April 2019

Ten garlic genotypes of released varieties and local cultivar were evaluated during the period May to September 2017 at farmer's fields in two locations of Kanthalloor panchayat of Idukki district. The results showed that the genotypes differed significantly in both yield and quality aspects. The local cultivar and Yamuna safed-3 recorded highest equatorial diameter and bulb weight. The number of cloves per bulb was as high as 16 in AAS-2. The genotype Yamuna safed-3 recorded a highest yield of $1.19 \mathrm{Kg} / 2 \mathrm{~m}^{2}$ followed by local cultivar and Ooty- $1\left(0.90 \mathrm{Kg} / 2 \mathrm{~m}^{2}\right.$ and $0.89 \mathrm{Kg} / 2 \mathrm{~m}^{2}$ respectively). While considering both yield and quality aspects in trade, local cultivar, Yamuna Safed-3 and Ooty-1 were found to be the promising genotypes.
\end{abstract}

\section{Introduction}

Garlic (Allium sativum L.), a member of family Alliaceae is the second important bulb crop grown after onion. India ranks second to China in area and production of garlic in the world. In Kerala, garlic cultivation is confined to an area of 80 ha with a production of $630 \mathrm{t}$ (DASD, 2016) and it is commercially grown in Kanthalloor and Vattavada panchayats in Devikulam block of Idukki district.

Garlic is widely used for its pungent flavour as a seasoning or condiment. Allicin (diallylthiosulfinate), is the volatile compound responsible for the pungent smell of garlic and most of the medicinal effects are attributed to this sulphur compound. Its nutritive value is very high among the bulbous crops. Fresh peeled garlic cloves contain $62.8 \%$ moisture, $29 \%$ carbohydrate, $6.3 \%$ protein, $1 \%$ mineral matter, $0.8 \%$ fibre, $0.1 \%$ fat, $0.31 \%$ phosphorus, $0.03 \%$ calcium, $0.001 \%$ iron, $13 \mathrm{mg} / 100 \mathrm{~g}$ vitamin $\mathrm{C}$ and $0.4 \mathrm{mg} / 100 \mathrm{~g}$ nicotinic acid (Chadha and Kalloo, 1993).

A wide range of adaptability of garlic to different soil types, temperatures and day length makes its cultivation possible from tropics to temperate region. Studies conducted by Volk and Stern, 2009 suggested that 
cultivars grown under diverse climatic condition have highly elastic environmental response, particularly relating to skin colour and yield. Information on the performance of improved garlic varieties in the traditional growing tract of Kerala is lacking. It is in this background that the present study was undertaken with an objective to evaluate the performance of various garlic genotypes for yield and quality in the Kanthalloor panchayat of Idukki district.

\section{Materials and Methods}

The study was conducted at farmer's fields in two locations of Kanthalloor panchayat of Idukki district which comes under Marayur Dry Hills Agro Ecological Unit number 17. The area lies between $10^{\circ} 13^{\prime} \mathrm{N}$ latitude and $77^{\circ} 11^{\prime} \mathrm{E}$ longitude with an altitude of $5800 \mathrm{ft}$ above Mean Sea Level. Soil texture of the experimental site was loam to clay loam. The area represents low rainfall region having a tropical sub humid monsoon climate with an average annual temperature of $23.08^{\circ} \mathrm{C}$ and rainfall of $1703.71 \mathrm{~mm}$.

The study comprises evaluation of ten varieties viz. Yamuna Safed, Yamuna Safed2, Yamuna Safed-3, Yamuna Safed-8, Yamuna Safed-9, BhimaOmkar, Bhima Purple, AAS-2, Ooty-1 and local cultivar. The seed cloves of garlic genotypes were dibbled in flat beds of $2 \mathrm{~m}^{2}$ size at a spacing of $15 \mathrm{~cm} \mathrm{x}$ $8 \mathrm{~cm}$ in randomized block design with three replications. The recommended package of practices of KAU (2016) was followed for raising the crop during May-September 2017.

The bulbs were harvested at maturity and the observations on quantitative bulb characters i.e. equatorial diameter $(\mathrm{cm})$, polar diameter (cm), fresh bulb weight (g), cured bulb weight (g), number of cloves per bulb and clove weight (g) were taken from ten randomly selected garlic bulbs. Yield per plot $(\mathrm{Kg})$ and estimated yield per hectare ( $\mathrm{t}$ ) were also recorded. Pooled analysis of the two fields was done to study the combined effect.

Observations were also recorded on biochemical parameters of harvested garlic bulbs at maturity. TSS ( ${ }^{\circ}$ Brix), total sugar $(\%)$, ascorbic acid (mg/100g), pungency $(\mu \mathrm{M} / \mathrm{g})$, essential oil $(\%)$ and oleoresin $(\%)$ were estimated. The data were statistically analysed to test the significance of difference among the genotypes. The genotypes were ranked to find out superior genotypes.

\section{Results and Discussion}

\section{Yield characters}

Quantitative bulb characters of garlic genotypes are shown in Table 1. Local cultivar and Yamuna Safed-3 recorded a higher equatorial diameter $(3.28 \mathrm{~cm}$ and $3.09 \mathrm{~cm}$ respectively) and the equatorial diameter of Ooty-1 $(2.97 \mathrm{~cm})$ was comparable. Yamuna Safed-3 also recorded a highest polar diameter of $3.62 \mathrm{~cm}$ and the local cultivar recorded a comparable value of $3.46 \mathrm{~cm}$.

Umamaheswarappa et al., (2014) reported that the cultivar Yamuna Safed-3 recorded a highest equatorial and polar diameter $(3.04 \mathrm{~cm}$ and $3.72 \mathrm{~cm}$ respectively) in his study under central dry zone of Karnataka. Polar diameter and equatorial diameter determine the shape and size of the bulb which is an important attribute for its market value (Ratan et al., 2017).

Bulb weight is the most important yield contributing component (Sandhu et al., 2015 and Sharma et al., 2015). In the present study local cultivar and Yamuna Safed-3 recorded the higher fresh bulb weight (15.66g and $15.31 \mathrm{~g}$ respectively) and cured bulb weight $(12.33 \mathrm{~g}$ and $11.14 \mathrm{~g}$ respectively) followed by Ooty-1. It was also reported that the variety 
Yamuna Safed-3 develop good bulbs in southern hills (Chadha, 2003). Yamuna Safed-2 was poor in performance when both fresh bulb weight and cured bulb weight were concerned $(5.30 \mathrm{~g}$ and $3.80 \mathrm{~g}$ respectively).

Enormous variability was observed in the number of cloves per bulb. Genotype AAS-2 recorded highest number of cloves (16.83) and lowest number of cloves per bulb was observed in Yamuna Safed-8 (2.81) which failed to differentiate cloves in the Kanthalloor agro ecological situation in the season May to September. About 79.16 per cent of the bulbs produced were single clove bulbs in Yamuna Safed-8. Number of clove was low as 5.55 in Yamuna Safed-2, which also lacks clove differentiation property and there was $25.17 \%$ single clove bulbs in the experimental field.

Highest clove weight was recorded in local cultivar $(1.21 \mathrm{~g})$ and Ooty-1 $(1.20 \mathrm{~g})$ setting apart Yamuna Safed-8 (2.84g) which failed in clove differentiation. The number of cloves per bulb was also goodi.e.13.33 and 12.08 in local cultivar and Ooty-1 respectively. Though AAS-2 recorded the highest number of cloves per bulb (16.83) clove weight was as low as $0.44 \mathrm{~g}$ which is the character of that particular Karnataka genotype. But it is not an acceptable trait from the point of consumer preference. Garlic, being a multicloved crop the emphasis should be given to big and bold cloved bulbs rather than bulb with too many cloves (Agarwal and Tiwari, 2005).

Yield is a complex character influenced by the varietal characters and the environmental conditions where the plant has grown. The genotype Yamuna Safed-3 recorded a highest yield $(1.19 \mathrm{Kg} / \mathrm{plot}$ and $5.96 \mathrm{t} / \mathrm{ha}$ ) followed by local cultivar $(0.90 \mathrm{Kg} / \mathrm{plot}$ and $4.48 \mathrm{t} / \mathrm{ha})$ and Ooty-1 $(0.89 \mathrm{Kg} /$ plot and $4.47 \mathrm{t} / \mathrm{ha})$ (Table 1 and Fig. 1). The genotype Yamuna Safed-3 is a selection from a local collection obtained from Tamil Nadu, which may attributes to its better performance in terms of yield in the studied agro climatic conditions.

The estimated yield of Yamuna Safed-3 and local cultivar were 5.96t/ha and 4.48t/ha respectively which is in tune to the yield reported by Umamaheswarappa et al., (2014), who noted that the variety Yamuna Safed-3 recorded a high total yield (6.15t/ha) and marketable yield (5.23t/ha) under central dry zone of Karnataka. It was also reported a yield of 5.80t/ha under subtropical environment of Jammu (Kumar et al., 2015).

\section{Quality parameters}

The biochemical characters of different garlic genotypes are depicted in Table 2. The genotype Bhima Omkar recorded a high TSS value of $35.93^{\circ}$ Brix and Yamuna Safed-2 was on par $\left(34.5^{\circ} \mathrm{Brix}\right)$. The lowest TSS was recorded in the genotypes Ooty-1 $\left(28.97^{\circ}\right.$ Brix $)$ and local cultivar $\left(29.07^{\circ}\right.$ Brix $)$. According to the reports of study by Agarwal and Tiwari (2005) and Sharma et al., (2015), the lines which are having high total soluble solids can be stored for longer duration. The genotype Yamuna Safed-3 had a considerably good TSS content of $34.10^{\circ}$ Brix, when compare with local cultivar and Ooty-1.

Total sugar content of Bhima Purple was higher $(37.60 \%)$. It was lowest in local cultivar $(19.83 \%)$. Ascorbic acid content of garlic genotypes was found to vary from $7.53 \mathrm{mg} / 100 \mathrm{~g}$ to $17.77 \mathrm{mg} / 100 \mathrm{~g}$. It was highest in Ooty-1 $(17.77 \mathrm{mg} / 100 \mathrm{~g})$ and Yamuna Safed-8 was comparable $(15.22 \mathrm{mg} / 100 \mathrm{~g})$. But the high yielding genotypes, local cultivar and Yamuna Safed-3 were found to be low in ascorbic acid content.

Pungency of Yamuna Safed-8, which had $79.16 \%$ of single clove bulbs, was higher $(74.00 \mu \mathrm{M} / \mathrm{g})$ than other genotypes followed 
by Ooty-1 $(59.48 \mu \mathrm{M} / \mathrm{g})$ and local cultivar $(57.93 \mu \mathrm{M} / \mathrm{g})$. The high yielding genotype Yamuna Safed-3 recorded a pungency of $52.94 \mu \mathrm{M} / \mathrm{g}$.

Essential oil was highest in the genotype Yamuna Safed-9 (0.35\%) and Yamuna Safed $(0.34 \%)$ and the essential oil content of Bhima Purple and local cultivar $(0.3 \%)$ were comparable. El-Sayed et al., (2017) reported nearly $60 \%$ higher essential oil content in the purple-skin garlic compared to white skinned garlic. Yamuna Safed-9 is a purple skin genotype which also recorded highest essential oil content compared to other genotypes. Highest oleoresin content of $2.06 \%$ was recorded in AAS-2 and Yamuna Safed $(1.80 \%)$ was on par.

Table.1 Yield characters of different garlic genotypes

\begin{tabular}{|l|l|l|l|l|l|l|l|}
\hline \multicolumn{1}{|c|}{ Genotypes } & $\begin{array}{c}\text { Equatorial } \\
\text { diameter } \\
(\mathbf{c m})\end{array}$ & $\begin{array}{c}\text { Polar } \\
\text { diameter } \\
(\mathbf{c m})\end{array}$ & $\begin{array}{c}\text { Fresh bulb } \\
\text { weight }(\mathbf{g})\end{array}$ & $\begin{array}{c}\text { Cured } \\
\text { bulb } \\
\text { weight }(\mathbf{g})\end{array}$ & $\begin{array}{c}\text { Number of } \\
\text { cloves/bulb }\end{array}$ & $\begin{array}{c}\text { Clove } \\
\text { weight }(\mathbf{g})\end{array}$ & $\begin{array}{c}\text { Yield/ } \\
\text { plant } \\
(\text { Kg) }\end{array}$ \\
\hline Yamuna Safed & $2.42^{\text {cd }}$ & $3.28^{\mathrm{bc}}$ & $7.22^{\mathrm{c}}$ & $5.76^{\mathrm{bc}}$ & $9.38^{\mathrm{cd}}$ & $1.06^{\mathrm{bcd}}$ & $0.50^{\mathrm{c}}$ \\
\hline Yamuna Safed-2 & $1.94^{\mathrm{f}}$ & $2.66^{\mathrm{e}}$ & $5.30^{\mathrm{c}}$ & $3.80^{\mathrm{d}}$ & $5.55^{\mathrm{ef}}$ & $1.17^{\mathrm{bc}}$ & $0.44^{\mathrm{c}}$ \\
\hline Yamuna Safed-3 & $3.09^{\mathrm{a}}$ & $3.62^{\mathrm{a}}$ & $15.31^{\mathrm{a}}$ & $11.14^{\mathrm{a}}$ & $14.47^{\mathrm{ab}}$ & $0.91^{\mathrm{bcd}}$ & $1.19^{\mathrm{a}}$ \\
\hline Yamuna Safed-8 & $2.00^{\mathrm{ef}}$ & $2.84^{\mathrm{de}}$ & $6.74^{\mathrm{c}}$ & $5.25^{\mathrm{cd}}$ & $2.81^{\mathrm{f}}$ & $2.84^{\mathrm{a}}$ & $0.60^{\mathrm{c}}$ \\
\hline Yamuna Safed-9 & $2.32^{\text {de }}$ & $3.12^{\mathrm{c}}$ & $7.85^{\mathrm{c}}$ & $5.43^{\mathrm{bcd}}$ & $6.38^{\mathrm{e}}$ & $0.78^{\mathrm{bcde}}$ & $0.63^{\mathrm{bc}}$ \\
\hline BhimaOmkar & $2.39^{\mathrm{cd}}$ & $3.15^{\mathrm{c}}$ & $7.44^{\mathrm{c}}$ & $5.46^{\mathrm{bcd}}$ & $7.60^{\mathrm{de}}$ & $0.74^{\mathrm{cde}}$ & $0.49^{\mathrm{c}}$ \\
\hline Bhima Purple & $2.38^{\mathrm{cd}}$ & $2.78^{\mathrm{e}}$ & $6.83^{\mathrm{c}}$ & $4.80^{\mathrm{cd}}$ & $7.53^{\mathrm{de}}$ & $0.70^{\mathrm{de}}$ & $0.51^{\mathrm{c}}$ \\
\hline AAS-2 & $2.71^{\mathrm{bc}}$ & $2.68^{\mathrm{e}}$ & $7.33^{\mathrm{c}}$ & $6.32^{\mathrm{bc}}$ & $16.83^{\mathrm{a}}$ & $0.44^{\mathrm{e}}$ & $0.66^{\mathrm{bc}}$ \\
\hline Ooty-1 & $2.97^{\mathrm{ab}}$ & $3.10^{\mathrm{cd}}$ & $11.04^{\mathrm{b}}$ & $7.24^{\mathrm{b}}$ & $12.08^{\mathrm{bc}}$ & $1.20^{\mathrm{b}}$ & $0.89^{\mathrm{b}}$ \\
\hline Local cultivar & $3.28^{\mathrm{a}}$ & $3.46^{\mathrm{ab}}$ & $15.66^{\mathrm{a}}$ & $12.33^{\mathrm{a}}$ & $13.33^{\mathrm{b}}$ & $1.21^{\mathrm{b}}$ & $0.90^{\mathrm{b}}$ \\
\hline CD $(\mathbf{0 . 0 5})$ & 0.34 & 0.28 & 2.72 & 1.90 & 2.861 & 0.432 & 0.28 \\
\hline
\end{tabular}

Table.2 Biochemical characters of different garlic genotypes

\begin{tabular}{|l|l|l|l|l|l|l|}
\hline \multicolumn{1}{|c|}{ Genotypes } & \multicolumn{1}{|c|}{$\begin{array}{c}\text { TSS } \\
\left({ }^{\mathbf{B}} \mathbf{B r i x}\right)\end{array}$} & $\begin{array}{c}\text { Total } \\
\text { sugar }(\boldsymbol{\%})\end{array}$ & $\begin{array}{c}\text { Ascorbic acid } \\
(\mathbf{m g} / \mathbf{1 0 0 g})\end{array}$ & $\begin{array}{c}\text { Pungency } \\
(\boldsymbol{\mu M} \mathbf{M})\end{array}$ & $\begin{array}{c}\text { Essential } \\
\text { Oil }(\boldsymbol{\%})\end{array}$ & $\begin{array}{c}\text { Oleoresin } \\
(\boldsymbol{\%})\end{array}$ \\
\hline Yamuna Safed & $33.77^{\mathrm{b}}$ & $30.93^{\mathrm{cd}}$ & $12.68^{\mathrm{bc}}$ & $36.02^{\mathrm{f}}$ & $0.34^{\mathrm{a}}$ & $1.80^{\mathrm{ab}}$ \\
\hline Yamuna Safed-2 & $34.57^{\mathrm{ab}}$ & $34.94^{\mathrm{ab}}$ & $10.18^{\mathrm{cd}}$ & $55.01^{\mathrm{bcd}}$ & $0.21^{\mathrm{cd}}$ & $1.11^{\mathrm{c}}$ \\
\hline Yamuna Safed-3 & $34.10^{\mathrm{b}}$ & $24.60^{\mathrm{e}}$ & $12.65^{\mathrm{bc}}$ & $52.94^{\mathrm{cd}}$ & $0.25^{\mathrm{bc}}$ & $1.06^{\mathrm{c}}$ \\
\hline Yamuna Safed-8 & $30.07^{\mathrm{cd}}$ & $30.74^{\mathrm{cd}}$ & $15.22^{\mathrm{ab}}$ & $74.00^{\mathrm{a}}$ & $0.12^{\mathrm{e}}$ & $1.28^{\mathrm{bc}}$ \\
\hline Yamuna Safed-9 & $33.63^{\mathrm{b}}$ & $34.27^{\mathrm{abc}}$ & $12.69^{\mathrm{bc}}$ & $55.93^{\mathrm{bc}}$ & $0.35^{\mathrm{a}}$ & $1.29^{\mathrm{bc}}$ \\
\hline BhimaOmkar & $35.93^{\mathrm{a}}$ & $33.78^{\mathrm{abc}}$ & $12.72^{\mathrm{bc}}$ & $50.88^{\mathrm{d}}$ & $0.16^{\mathrm{de}}$ & $0.90^{\mathrm{c}}$ \\
\hline Bhima Purple & $33.47^{\mathrm{b}}$ & $37.60^{\mathrm{a}}$ & $12.71^{\mathrm{bc}}$ & $55.86^{\mathrm{bc}}$ & $0.30^{\mathrm{ab}}$ & $1.06^{\mathrm{c}}$ \\
\hline AAS-2 & $31.53^{\mathrm{c}}$ & $28.51^{\mathrm{d}}$ & $10.07^{\mathrm{cd}}$ & $43.06^{\mathrm{e}}$ & $0.16^{\mathrm{de}}$ & $2.06^{\mathrm{a}}$ \\
\hline Ooty-1 & $28.97^{\mathrm{d}}$ & $32.12^{\mathrm{bcd}}$ & $17.77^{\mathrm{a}}$ & $59.48^{\mathrm{b}}$ & $0.15^{\mathrm{e}}$ & $1.23^{\mathrm{bc}}$ \\
\hline Local cultivar & $29.07^{\mathrm{d}}$ & $19.83^{\mathrm{f}}$ & $7.53^{\mathrm{d}}$ & $57.93^{\mathrm{b}}$ & $0.30^{\mathrm{ab}}$ & $1.18^{\mathrm{bc}}$ \\
\hline CD $(\mathbf{0 . 0 5})$ & 1.71 & 3.89 & 4.56 & 4.98 & 0.06 & 0.66 \\
\hline
\end{tabular}


Table.3 Ranking of garlic genotypes based on yield and quality

\begin{tabular}{|l|l|l|l|l|l|l|l|}
\hline \multicolumn{1}{|c|}{ Genotypes } & $\begin{array}{l}\text { Clove } \\
\text { weight }\end{array}$ & \multicolumn{1}{|c|}{ Yield } & $\begin{array}{c}\text { Fresh bulb } \\
\text { weight }\end{array}$ & $\begin{array}{c}\text { Essential } \\
\text { oil }\end{array}$ & Pungency & Total & Rank \\
\hline Yamuna Safed & $9 / 15$ & $3 / 3$ & $3 / 3$ & $6 / 6$ & $1 / 5$ & 3.8 & \\
\hline $\begin{array}{l}\text { Yamuna Safed- } \\
\mathbf{2}\end{array}$ & $5 / 10$ & $3 / 3$ & $3 / 3$ & $9 / 18$ & $7 / 10$ & 3.7 & \\
\hline $\begin{array}{l}\text { Yamuna Safed- } \\
\mathbf{3}\end{array}$ & $9 / 15$ & $1 / 3$ & $1 / 3$ & $7 / 12$ & $5 / 10$ & $\mathbf{2 . 3 4}$ & II \\
\hline $\begin{array}{l}\text { Yamuna Safed- } \\
\mathbf{8}\end{array}$ & $1 / 5$ & $3 / 3$ & $3 / 3$ & $1 / 6$ & $5 / 5$ & 3.37 & \\
\hline $\begin{array}{l}\text { Yamuna Safed- } \\
\text { 9 }\end{array}$ & $14 / 20$ & $5 / 6$ & $3 / 3$ & $5 / 12$ & $1 / 5$ & 3.15 & \\
\hline BhimaOmkar & $12 / 15$ & $3 / 3$ & $3 / 3$ & $4 / 6$ & $9 / 10$ & 4.37 & \\
\hline Bhima Purple & $9 / 10$ & $3 / 3$ & $3 / 3$ & $5 / 12$ & $3 / 10$ & 3.62 & \\
\hline AAS-2 & $5 / 5$ & $5 / 6$ & $3 / 3$ & $3 / 6$ & $9 / 10$ & 4.23 & \\
\hline Ooty-1 & $2 / 5$ & $2 / 3$ & $2 / 3$ & $2 / 6$ & $5 / 5$ & $\mathbf{3 . 0 7}$ & III \\
\hline Local cultivar & $2 / 5$ & $2 / 3$ & $1 / 3$ & $2 / 6$ & $3 / 10$ & $\mathbf{2 . 0 3}$ & I \\
\hline
\end{tabular}

Fig.1 Estimated yield of garlic genotypes

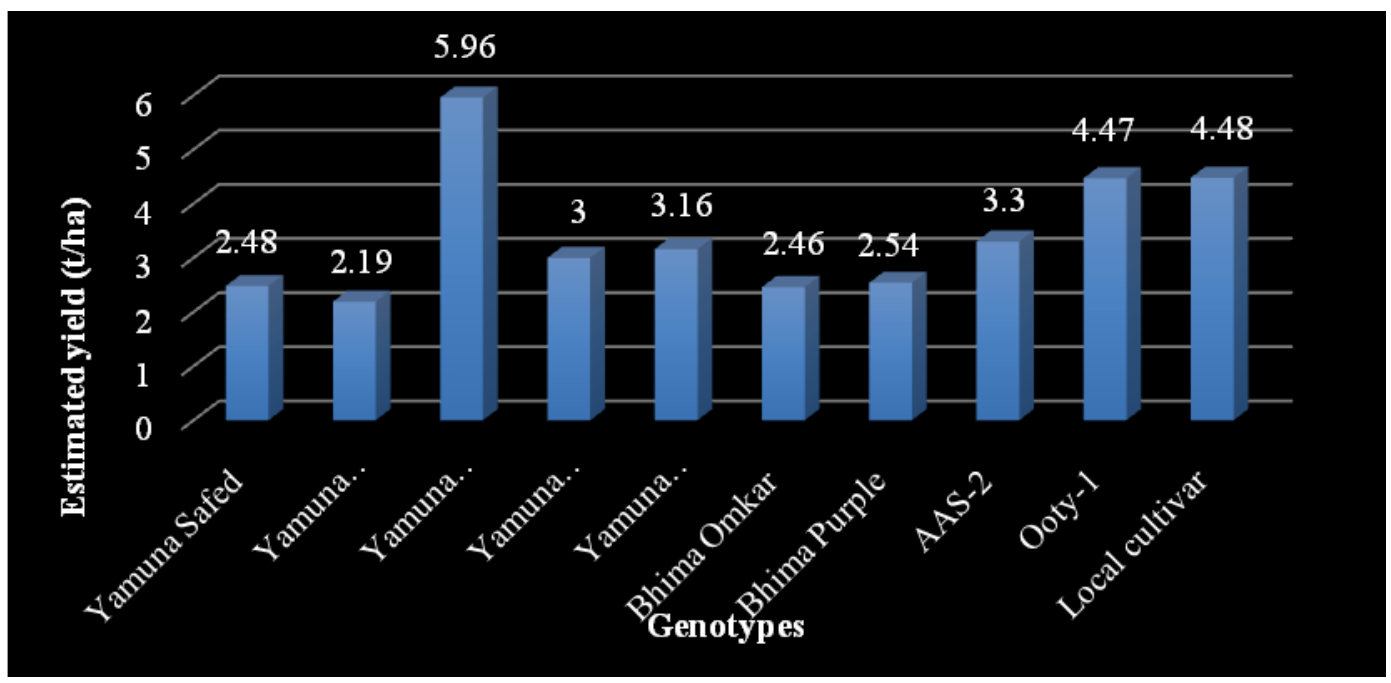

\section{Ranking of garlic genotypes}

Considering the important yield and quality aspects in trade, garlic genotypes were ranked using a method suggested by Arunachalam and Bandyopadhyay (1984). When the genotypes were compared based on yield characters, Yamuna Safed-3 and local cultivar were found to be the high yielders. But, when they were ranked based on both yield and quality viz.yield, fresh bulb weight, clove weight, essential oil content and pungency, the local cultivar was found to be the promising genotype over Yamuna Safed-3 (Table 3).

In conclusion, in the present study, the local cultivar and Yamuna Safed-3 recorded a higher equatorial diameter, fresh bulb weight and cured bulb weight and AAS-2 recorded highest number of cloves per bulb. Yamuna Safed-3 recorded highest yield per plot followed by the local cultivar and Ooty-1. The local cultivar was found to be the promising genotype over Yamuna Safed-3 when both yield and quality 
aspects are taken into consideration. In the present study, among the ten garlic genotypes studied, local cultivar, Yamuna Safed-3 and Ooty-1 were found to be the promising genotypes while considering both yield and quality aspects.

\section{Acknowledgement}

The authors wish to express sincere thanks to Kerala Agricultural University for the financial assistance. Express their gratitude to Dr. Nalini P. V., Dr. Miniraj N., and Dr. S. Krishnan, College of Horticulture for their valuable suggestions.Acknowledgements are also owe to DOGR, Pune and NHRDF, Rajasthan for supply of seed materials.

\section{References}

Agarwal, A. and Tiwari, R. S. 2005. Plant aechitecture affecting yield and incidence of purple blotch in garlic (Allium sativum). Natl. J. Plant. Improv. 7(1): 1-5.

Arunachalam, V. and Bandyopadhyay, A. 1984. A method to make decision jointly on a number of dependent characters. Indian $\mathbf{J}$. Genet. 44(3): 419-424.

Chadha, K. L. and Kalloo, G. 1993. Advances in Horticulture Vol. 13. In: Pandey, U. C. and Singh, J. Agro-techniques for Onion and Garlic. Malhotra publishing house, New Delhi, p. 451.

Chadha, K. L. 2003. Handbook of Horticulture. Directorate of Knowledge Management in Agriculture, ICAR, Pusa, New Delhi, p. 404.

DASD [Directorate of Arecanut and Spices Development] 2016. Spices Statistics at a Glance 2016. Directorate of Arecanut and Spices Development, Kozhikode, 156p.
El-Sayed, H. S., Chizzola, R., Ramadan, A. A., and Edris, A. E. 2017. Chemical composition and antimicrobial activity of garlic essential oils evaluated in organic solvent, emulsifying, and selfmicroemulsifying water based delivery systems. Food Chem. 221: 196-204.

Kumar, S., Samnotra, R. K., Kumar, M., and Khar, S. 2015. Character association and path analysis in garlic (Allium spp.) germplasm under sub tropical environment of Jammu. Bioscan 10(4): 1997-2003.

Ratan, D., Gowda, R. V., and Pandey, H. 2017. Evaluation of different onion (Allium сера L.) genotypes for yield and quality parameters in kharif season under Bengaluru condition, India. Intl. J. Curr. Microbiol. App. Sci6(11): 2393-2398.

Sandhu, S. S., Brar, P. S., and Dhall, R. K. 2015. Variability of agronomic and quality characteristics of garlic (Allium sativumL.) ecotypes. SABRAO J. Breed. Genet. 47(2): 133-142.

Sharma, D., Banyal, S. K., and Jarial, K. 2015. Studies on the performance of some garlic genotypes (Allium sativum L.) under subtropical conditions of Himachal Pradesh. J. Spices Aromat. Crops 24(2): 106-111.

Umamaheswarappa, P., Chandrappa, H., and Prasad, K. T. R. 2014. Evaluation of garlic (Allium sativum L.) genotypes for growth and yield traits under central dry zone of Karnataka. Environ. Ecol. 32 (2): 638-641.

Volk, M. K. and Stern, D. 2009. Phenotypic characteristics of ten garlic cultivar grown at different North American locations. Hort Science, 44(5): 1238-1247.

\section{How to cite this article:}

Shibana, S.N. and Jalaja S. Menon. 2019. Comparative Evaluation of Garlic (Allium sativum L.)Genotypes in Kanthalloor, Idukki, Kerala. Int.J.Curr.Microbiol.App.Sci. 8(04): 798-803. doi: https://doi.org/10.20546/ijcmas.2019.804.088 